\title{
Wel een schakeljaar in de basisopleiding geneeskunde ${ }^{1}$
}

\author{
W.P.J. van Oosterhout • M. Morsink
}

Binnen een aantal medische opleidingen wordt op dit moment geëxperimenteerd met het zogenaamde schakeljaar. Het schakeljaar - als laatste jaar van de basisopleiding geneeskunde - biedt mogelijkheden tot een efficiëntere aansluiting van de basisopleiding op de specialistische vervolgopleiding. Enerzijds heeft het het karakter van een studieperiode, anderzijds bereidt het voor op een medisch-specialistische vervolgopleiding. De werkervaring en de competenties die de zogenoemde semi-arts verwerft, leiden tot een soepeler overgang van coassistent naar arts en tot een mogelijke verkorting van de vervolgopleiding. Ook wanneer de opleidingsduur niet werkelijk wordt verkort, heeft het schakeljaar nut als oriëntatie-, verdiepings- en profileringsfase met een grotere kans op toelating tot een vervolgopleiding. ${ }^{1}$

Het KNMG Studentenplatform is voor spoedige invoering van het schakeljaar op alle acht medische faculteiten. Net zoals bepleit wordt in het rapport "De arts van straks", en overeenkomstig de voorkeur van $71 \%$ van de respondenten van het in 2004 onder KNMG-studentleden uitgevoerde studentenpanel, wil het KNMG Studentenplatform dat basis- en vervolgopleiding sneller kunnen worden afgerond. ${ }^{1}$ Het schakeljaar is een belangrijke rol toebedeeld, omdat het een soepele doorstroming zou bevorderen. ${ }^{1-2}$ Eerder dit jaar heeft de Stuurgroep Modernisering Opleidingen en Beroepsuitoefening in de Gezondheidszorg - het door het ministerie van Volksgezondheid, Welzijn en Sport geïnitieerde orgaan dat als doel heeft de beroepenstructuur en de zorgopleidingen te moderniseren - samen met de KNMG Colleges een werkconferentie over het schakeljaar georganiseerd. De landelijke invoering van het schakeljaar lijkt hiermee prioriteit te hebben gekregen.

Om het schakeljaar als daadwerkelijke 'schakel' te laten functioneren zal aan een aantal voorwaarden voldaan moeten zijn. Ten eerste zal het voorafgaande curriculum inhoudelijk moeten zijn aangepast, zodat studenten eerder in hun opleiding meer klinische ervaring opdoen. Wellicht kunnen dan ook de eindtermen van vervolgopleidingen in een kortere periode worden behaald.Ten tweede is, vanwege de grotere verantwoordelijkheid van de semi-arts, intensieve, continue en vakoverstijgende begeleiding door een mentor essentieel bij de ontwikkeling tot arts. Aangezien het schakeljaar eveneens een onderwijsjaar is en niet primair arbeidskrachten levert, is een heldere functieomschrijving van de semiarts noodzakelijk. Ten derde heeft het vroeger uitspreken van een voorkeur voor een specialisme gevolgen. Het blijkt moeilijk om al in het vijfde studiejaar een specialisme te kiezen. ${ }^{3}$ De verschillende profielen die de studenten kunnen kiezen voor hun schakeljaar moeten volledige keuzevrijheid van de student garanderen. Dit kan logistieke problemen opleveren. Daarnaast moeten de te kiezen profielen voldoende breed zijn, waarbij een gekozen profiel een student niet mag belemmeren in een eventuele keuze voor een andere vervolgopleiding. ${ }^{4}$

Het schakeljaar kan onder deze voorwaarden bijdragen aan een soepele aansluiting van de basisopleiding op de vervolgopleiding. Spoedige invoering van het schakeljaar op alle geneeskundefaculteiten is aan te bevelen. Belangenconflict: geen gemeld.

Financiële ondersteuning: geen gemeld.

\section{Summary}

The 'schakeljaar' (connecting year) is the final year of the medical curriculum in which both education and the preparation for clinical activity as a resident are important features. Thus, a smooth transition from medical study to residency is guaranteed. However, a few criteria must be met. Firstly, sufficient knowledge, skills and

\footnotetext{
${ }^{1}$ Dit artikel verschijnt ook in het Nederlands Tijdschrift voor Geneeskunde.
} 
clinical independence must have been accumulated during the preceding years. Secondly, intensive supervision during the connecting year is indispensable for professional and personal development. Thirdly, a connecting year spent in a certain specialty should not interfere with the choice for residency in another specialty of interest. The students of the Dutch Medical Association support a rapid and nationwide introduction of a connecting year in all eight medical faculties. (Oosterhout WPJ van, Morsink M. A 'connecting year' is useful in the medical curriculum Dutch Journal of Medical Education 2007;26(4):195-196.)

\section{Literatuur}

Meyboom-de Jong B, Schmit Jongbloed LJ, Willemsen MC, redacteuren. De arts van straks. Een nieuw medisch opleidingscontinuüm. Utrecht: Koninklijke Nederlandsche Maatschappij tot Bevordering der Geneeskunst; 2002.
Rooijen APN van, redacteur. De zorg van morgen: flexibiliteit en samenhang. Ministerie van Volksgezondheid, Welzijn en Sport (VWS). Ministerie van Onderwijs, Cultuur en Wetenschap. Alphen aan den Rijn: Haasbeek; 2003.

Molenaar WM, Reinders JJ, Cohen-Schotanus J. De relatie tussen specialisme van keuzeco-schap en vervolgopleiding. Tijdschrift voor Medisch Onderwijs 2004;23:23-9.

Jong GM de, Rijken JJ. Brug tussen student en praktijk. Med Contact 2004;60:1643-5. 